\title{
form
}

Vol I4, No 2 (202I)

Marja-Leena Rönkkö

Senior Lecturer (PhD)

University of Turku

marja-leena.ronkko@utu.fi

Kaiju Kangas

Assistant Professor (PhD)

University of Helsinki

kaiju.kangas@helsinki.fi

\section{Learning everyday technologies through playful experimenting and cooperative making in pre-primary education}

\begin{abstract}
The Finnish National Core Curriculum for pre-primary education (FNBE, 2014) emphasizes the promotion of children's interests in science and technology, as well as in creative designing and making. The integrative STEAM approach is seen as promising for fostering students' creative competencies starting from early education stages. In pre-primary education, the STEAM framework has received little research interest; the empirical evidence of its implementation is especially limited. The objective of this present study is to explore pre-primary students' designing and making processes involving both traditional and digital craft elements, and how their learning of everyday technologies can be supported. The data consists of video recorded sessions, where pre-primary students ( $n=19$, aged 5-6 years) were creating felted "Power Creatures" with soft circuits. The results indicate that with adult and peer student cooperation, pre-primary students are able to create original creatures and use digital elements as a part of their craft product. Playing is endorsed as a learning method to support pre-primary education in both tangible and abstract elements of technology.
\end{abstract}

Keywords: STEAM education, everyday technologies, pre-primary students, soft circuit. 


\section{INTRODUCTION}

Technology has quickly become a part of young children's lives. The purpose of technology education in pre-primary education is to help children to understand everyday technology and how it can be used to solve daily life problems. (Sundqvist \& Nilsson, 2018; Turja et al., 2009.) One main goal of young children's technology education is to encourage children to observe technology and technological implementations surrounding them, and to evoke their interest in practical, hands-on ways. Children take part in the tasks, using age-appropriate materials, tools, and techniques, to creatively resolve their own technological matters. The main principles in young children's technology education are childcentered ways to act, use of imagination, and constructive play (Turja et al., 2009).

The Finnish National Core Curriculum for pre-primary education (FNBE, 2014) emphasizes the promotion of children's interest in science and technology, as well as in creative designing and making. In Finland, young children's technology education can be seen as a wide-ranging and practical early childhood education content, which has many common goals with other learning areas (FNBE, 2014), especially with crafts. Both of these learning areas include designing, creative problem solving, examining and experimenting with structures and materials, constructing (making), and reflection on the process and products. Children are encouraged to figure out and build various constructions or solutions to their own, self-found technological problems using versatile materials, and to verbally describe their decisions (FNBE, 2014; Turja, 2011). This type of learning process allows children to create personal and unique outputs and enables them to use their own experiences, knowledge, and observations while implementing the assignments (Aerila, Rönkkö \& Grönman, 2019). Thinking processes, designing, and hands-on making form a new perception of technology via self-made products

The integrative STEAM approach is seen as promising for fostering students' creative technological competencies starting from the early education stages (Lindeman, Jabot \& Berkley, 2014). STEAM stands for science, technology, engineering, arts and mathematics, which are the ways young children interact with their world on a daily basis (Lindeman et al., 2014). "A" is understood broadly to include not only arts, but design and humanities as well (Bequette \& Bequette, 2012). Within the STEAM framework, art, design, and the humanities are perceived as the keys to fostering creativity in all citizens (e.g., Sousa \& Pilecki, 2018) as well as to developing the type of cultural knowledge needed to deal with the problems facing the present and future world (e.g., Ge, Ifenthaler, \& Spector, 2015).

However, among young students, the STEAM framework has received little research interest; the empirical evidence of its implementation is especially limited. In this present study, we explore preprimary students' "Power Creatures" project, where technology education is integrated with art, design, and crafts. The STEAM approach is used as a framework for the project, as the children designed and constructed felted toys that included soft circuits in collaboration with older students, parents, and grandparents. In this paper, we focus on children's designing and making processes and on the support of learning of everyday technologies. We address the following research questions:

1. How to implement pre-primary students' designing and making processes involving both traditional and digital craft elements?

2. What kind of activities can be used to support pre-primary students' learning of everyday technologies?

\section{METHOD}

\section{Participants and the setting of the study}

The present research was conducted in a municipal preschool group in an urban area of western Finland as a part of the InnoPlay research project (https://blogit.utu.fi/innoplay/en/). The group consisted of 19 children (10 boys and 9 girls), aged 5 to 6 years. During a period of four months in fall 2019, the children designed and constructed "Power Creatures," which are felted toys with soft circuits and electronic components. The project goals were to learn the basics of everyday technologies in designing and 
making a felted craft product, to develop the skills of cooperation, and to boost children's self-esteem through the joy of making.

The project was planned by the pre-school manager and two early childhood teachers in the group. The teachers implemented the project together with an assistant who worked with the group on a daily basis. In addition, the researchers and project worker of the InnoPlay project discussed the plans with the teachers and helped to implement the making phase over four days. To ensure enough adult support for the children, they were usually divided into smaller groups, so there was only a small group of children in one project activity at the same time.

The structure of the Power Creatures project is presented in Table 1. The project was implemented during a total of 20 sessions, which lasted approximately 30-60 minutes each. The teachers started with an orientation phase, in which they led the children toward the project's themes by reading books aloud and guiding discussion and play related to self-esteem and electricity. After orientation, the children designed their projects and constructed them with the help of their parents and older students. At the end of the project, the children and teachers organized a Power Creatures exhibition at the preschool.

Table 1. Structure of the Power Creatures project

\begin{tabular}{|c|c|c|}
\hline Time & Main phases & External participants \\
\hline $\begin{array}{l}\text { September } \\
3 \text { sessions }\end{array}$ & $\begin{array}{l}\text { Orientation } \\
\text { Reading children's books on self-esteem and electricity, } \\
\text { discussions and play }\end{array}$ & \\
\hline \multirow[t]{3}{*}{$\begin{array}{l}\text { October } \\
7 \text { sessions }\end{array}$} & $\begin{array}{l}\text { Orientation } \\
\text { Learning the function of circuits through play and } \\
\text { experiments }\end{array}$ & \\
\hline & $\begin{array}{l}\text { Design } \\
\text { Designing the creatures by drawing }\end{array}$ & \\
\hline & $\begin{array}{l}\text { Making } \\
\text { Felting the pattern pieces of the creatures }\end{array}$ & $\begin{array}{l}\text { Parents and } 4 \text { th graders } \\
\text { As needed for assistance }\end{array}$ \\
\hline \multirow[t]{3}{*}{$\begin{array}{l}\text { November } \\
7 \text { sessions }\end{array}$} & $\begin{array}{l}\text { Making } \\
\text { Drawing patterns and cutting the felt } \\
\text { Needle felting the details }\end{array}$ & \\
\hline & $\begin{array}{l}\text { Making } \\
\text { Sewing the soft circuits }\end{array}$ & $\begin{array}{l}\text { 8th graders } \\
\text { As needed for assistance }\end{array}$ \\
\hline & $\begin{array}{l}\text { Making } \\
\text { Assembling the creatures }\end{array}$ & \\
\hline \multirow[t]{2}{*}{$\begin{array}{l}\text { December } \\
3 \text { session }\end{array}$} & $\begin{array}{l}\text { Story crafting } \\
\text { Telling stories about the creatures }\end{array}$ & $\begin{array}{l}\text { Grandparents } \\
\text { As writers of the children's } \\
\text { stories }\end{array}$ \\
\hline & $\begin{array}{l}\text { Exhibition } \\
\text { Building and staffing an exhibition of the Power Creatures }\end{array}$ & $\begin{array}{l}\text { Grandparents, Parents and } \\
\text { school students } \\
\text { As visitors }\end{array}$ \\
\hline
\end{tabular}

\section{Data collection and analysis}

The data consisted of video-recorded sessions of the project's orientation, design, and making phases. The data was collected with three GoPro cameras; one recorded an overview of the activities, and two were attached to two volunteer children's heads. Additional data included photos of children's sketches, designs, and finished products. 
The qualitative content analysis was a combination of theory-driven and data-driven approaches, which focused on characterizing the children's verbal and material activities and interaction during the process. The framework for the theory-driven analysis was based on the following themes: 1) children's understanding of everyday technologies (e.g., circuits) and 2) children as designers and makers. Two additional themes emerged from the data: 3 ) cooperation with school students, parents, and grandparents and 4) playful experimenting.

\section{RESULTS}

\section{The implementation of the designing and making process}

The Power Creatures project was introduced by reading picture books to the children related to the development of self-esteem. One book, Molli, was written by Finnish author Katri Kirkkopelto. Molli is a small and angry character who lives alone in the middle of a big garden. Molli dreams of having a friend to share secrets, to sit quietly together, and to play. The book includes pedagogical practices, such as drawing a "power poster" for supporting and developing children's emotional skills and self-regulation. The children and their teachers discussed the book's themes and played games related to these themes. In addition, the children were introduced to electricity and electrical safety with the help of The Electricity Book of Little John by The Finnish Association for Electrical Safety.

Based on the orientation activities, the children were guided to draw their Power Creatures as a design for their felted creatures. The drawing's objective was to illustrate where the children find strength in their everyday lives. In addition, the children designed the soft circuit included in the creature and the placement of electrical components, such as LED lights for eyes or other details.

In the making phase, the children felted two pieces (front and back) for their creatures. Felting was completed with help of their parents during a parents' evening at the preschool. In addition, fourth grade students (aged 9-10) helped the children to felt some extra pieces for the creatures. The children also drew patterns according to their creature designs, cut the felt pieces to shape, and added details with needle felting. Next, with help of eighth grade students (aged 13-14), the children sewed the soft circuits to the creatures using conductive thread, a coin battery holder, and LED lights (Figure 1). Before sewing the two sides of the creatures together, the children tested whether their circuits worked.

The process continued with reflection through the story crafting method (Rönkkö et al., 2021). Each child told a story about their creature, what kind of powers it gives to the child, and how the powers can be used. The children acted as narrators, and wrote the stories down verbatim. At the end of the project, the children and teachers organized a Power Creatures exhibition for the rest of the kindergarten children and staff. In addition, a separate exhibition was organized for the school students, parents, and grandparents who participated in the project. 


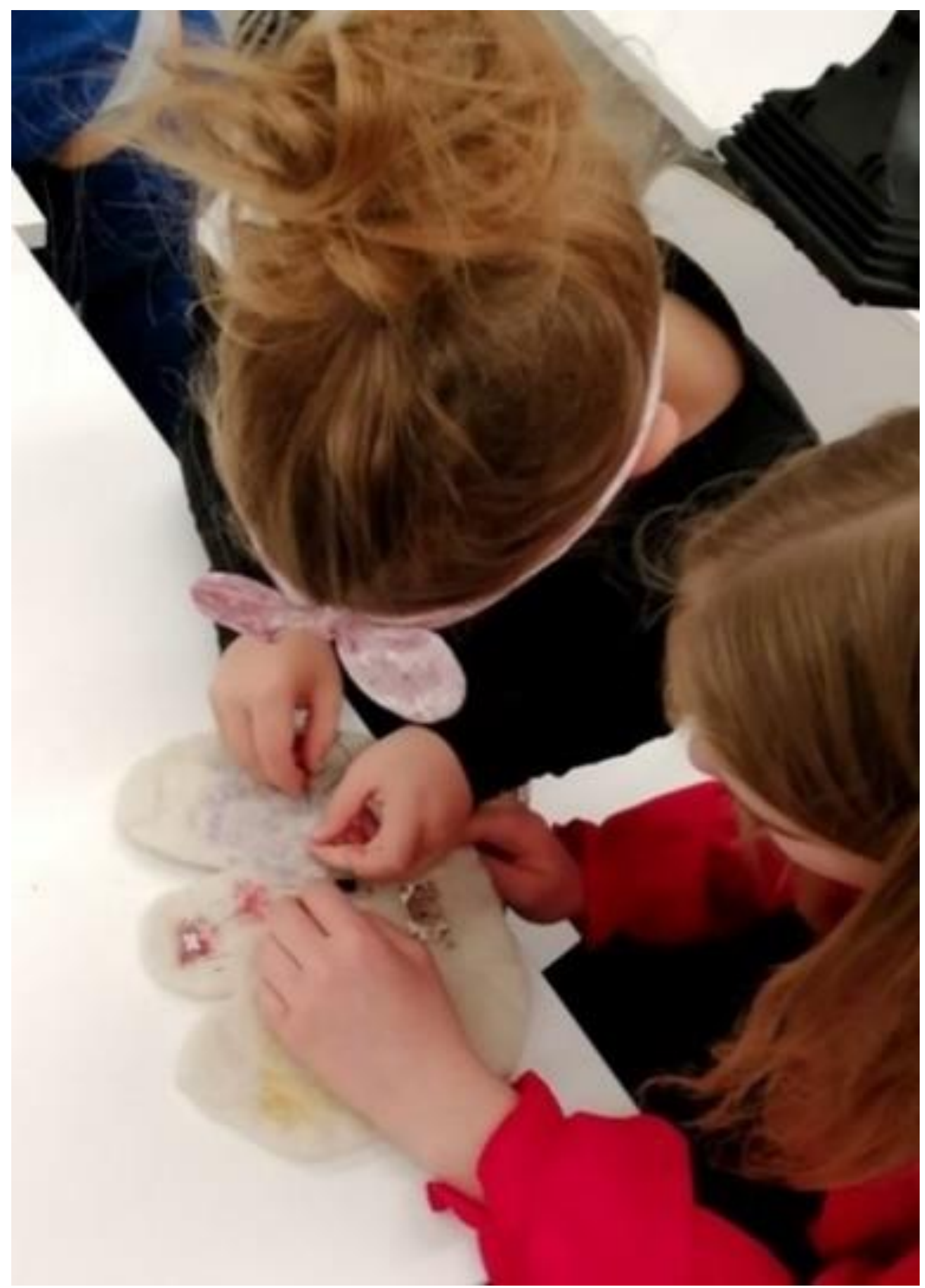

FIGURE 1. Cooperative sewing of the soft circuit. 

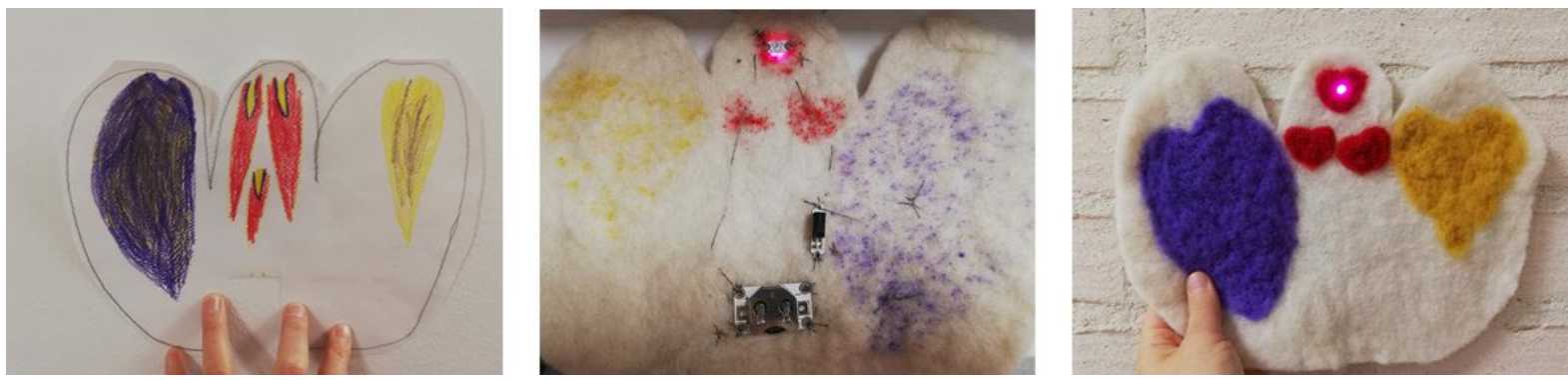

FIGURE 2. An example of a child's process from design to soft circuit and to a finished Power Creature.

Several researchers (e.g., Anning 1997; Hope 2008; Welch 1998) have stated that without guiding, children under 8 years rarely use two-dimensional models (i.e. sketches and drawings) as a blueprint for making a three-dimensional product. They have difficulties to see the link between the drawing and the future real product (Hope 2008). However, research has also shown that pre-primary-aged children are able to follow their plans when making three-dimensional art and craft products, and they can also make justifiable changes to their designs, if noticed during the making phase (Pavlou, 2009; Yliverronen, 2014). During the making phase, it is essential to guide children to revisit their designs, in order to reflect on their ideas and use the design as a tool when implementing the product (Fleer, 2000).

The present study revealed that children implemented their designs determinedly (Figure 2). They were all able to construct a felted creature with a soft circuit according to their designs. During making, the children checked details from the design, added some new ones, and wondered if the result looked like what they imagined. In this case, the similarity between the hand-drawn design and the flat, felted piece helped children to perceive the design as a basis for the final craft product. The making phase gives a tangible form to children's thoughts and designs; thus, they become familiar with the holistic craft process, which includes the phases of ideation, designing, making, and reflection (Pöllänen, 2019).

\section{The pedagogical facilitation for the learning of everyday technologies}

In the present study, two supportive elements were crucial to the pre-primary students' learning of everyday technologies. First, visualizing the functioning of a circuit through playful experimenting supported the children in understanding the basics of electricity. Second, support from older students, parents, and grandparents helped the children to implement their designs into tangible forms.

After reading The Electricity Book of Little John, playful experimentation was used as a method for understanding the components and function of a circuit. In circuit play, the children held each other's hands, and one of them acted as a switch (sending an impulse), the second as a buzzer, the third as a battery, and the rest of them as conducting bodies. This gave the children the initial idea of the circuit, which helped them to build a real circuit with actual components after the play. In pairs, they constructed a circuit with batteries, a battery holder, a switch, alligator clips, and a buzzer. Then, the children experimented with various materials (i.e., furniture, walls, floors) to see if the material is conductive or nonconductive (Figure 3). After a short book introduction and various hands-on activities, the children were able to design and make fully-functioning circuits for their creatures. Further, the experiences supported them in understanding electricity and the function of everyday electrical objects.

Cooperation with older students, parents, and grandparents was an established practice in the preschool and used regularly to facilitate the children's learning in various activities. The felting of the Power Creatures was supported by parents and fourth grade students. In general, the fourth graders are able to participate during the school year, and arrange, for example, plays during their breaks, common trips, or parties. In addition, eighth grade students supported the sewing of the soft circuits. They helped the children by making knots in the conductive thread, starting the sewing and showing how the stitches were made. This support was particularly important, as making soft circuits was a new activity for the children. It was also challenging for them because of the small components and slippery thread. 


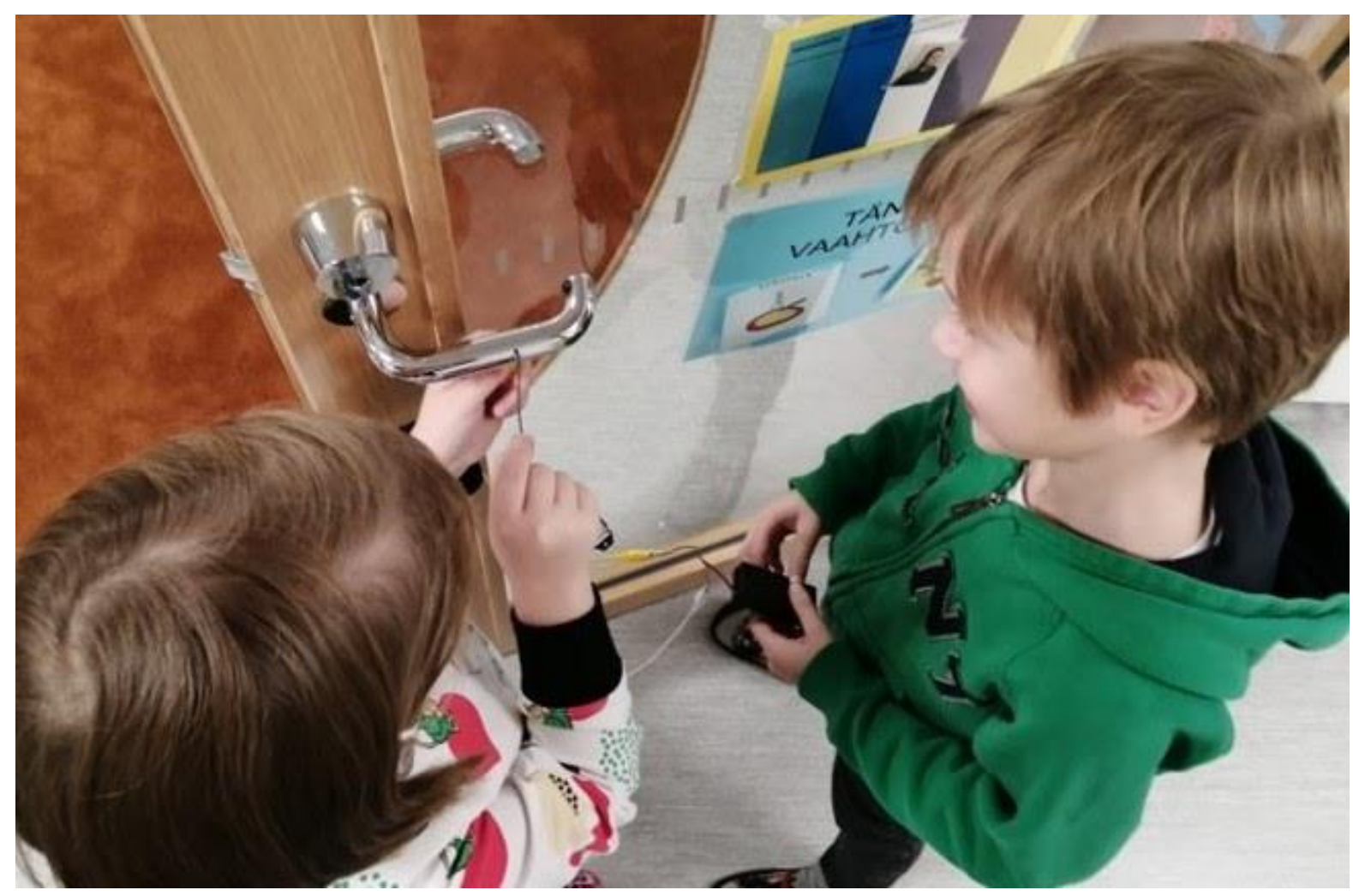

FIGURE 3. Children exploring conductive materials.

The results indicate that with playful experimentation and support from older students and/or adults, pre-primary students are able to create original creatures and use digital elements as part of their products. Further, through hands-on activities, they can learn issues related to everyday technologies and demonstrate this learning in tangible, self-made products.

\section{CONCLUSION}

The aim of the present study was to explore pre-primary students' Power Creatures project, where the children designed and constructed felted toys including soft circuits. The STEAM approach provided the framework for the project, which integrated technology education with art, design, and craft. In the study, we examined the implementation of the project, as well as the support of learning of everyday technologies.

The STEAM approach is motivated by the need to increase the creativity of all citizens (e.g., Sousa \& Pilecki, 2018). Creativity and innovation have become the recognized hope for solving multiple, difficult, and cumulative problems and risks related to climate change, the sustainability of the Earth, and radical inequality. Similarly, in the Power Creatures project, the emphasis was on creative activities. Instead of simply learning existing knowledge, the children learned to create their own knowledge related to technology, design, and making. This knowledge was visible in their playful experimentations with circuits, their ability to implement the holistic craft process, and in the creatures they designed and constructed.

Design is a crucial aspect of creative technological activities because designing gives visual form to one's thoughts. Design can refer to visual design (i.e., shapes, colors, patterns), but it also can refer to technical design (i.e., structure, function, construction). Both of these aspects are important educational goals in young children's craft and technology activities, even though technical design is often difficult for novices. In the Power Creatures project, technical design was supported with various playful experimentations, which aimed at developing the children's understanding of circuits and electricity. 
In pre-primary education, learning is generally holistic. Children learn by playing, moving, exploring, by working on different assignments, expressing themselves, and through activities based on arts (FNBE 2014). Because of this, children are typically very interested in small-scale investigations, such as observing daily life technological solutions and their functionality, examining phenomenon related to nature and technology, and making artifacts as a result of their experiences. Pre-primary educators should enable children to implement their thoughts and investigations by preparing the tasks convenient to children's age and skills and offering scaffolding on critical moments if needed. Scaffolding (help, such as prompts and hints) from a more skilled person is a crucial part of the learning process (Reiser \& Tabak, 2014). As craft makers, pre-primary students are curious, open-minded, and able to follow phases of the holistic craft process (Yliverronen, 2014). Pre-primary students' craft-making processes include the phases of experimental learning (Kolb, 1984) in proportion to children's age, where personal experience is based on reflective observation, perceiving, and active experimentation (Rönkkö \& Aerila, 2015).

Play is the basis for children's experiential learning (Leong \& Bodrova, 2012). The cognitive development of pre-primary-aged children goes through strong transformation. According to Piaget and Inhelder (1979), children are in the pre-operational stage, but concurrently, they are achieving the next concrete operational stage. During this stage, a child's thought processes become more mature. They start solving problems in a more logical fashion. Abstract thinking is not yet developed in the child, and because of this, children need concrete materials or experiences to support their problem solving and learning (Vygotsky, 1986).

Electronic textiles (e-textiles) are part of the growing body of maker activities (Kafai et al., 2014), but are not often used to familiarize young children with the basics of electronics and everyday technologies. Young students' designing and making often intertwine, and their designs develop while making. Cooperating with the eighth graders while sewing the soft circuits deepened this understanding, as it helped to give it a tangible form. According to Kafai et al. (2014), it is important to involve students in creating both the digital and the material modalities of learning. Successful collaborative working sessions with peers offer natural ways for scaffolding and supporting deep understanding (Sawyer 2006). Peer support is seen as a system of giving and receiving help with key elements of respect, shared responsibility, and mutual agreement of helpful activities (Mead et al., 2001). It is facilitated through a similar language between young people, and it gives the feeling of participation and school satisfaction (Mead \& MacNiel, 2004).

The operational culture of early childhood education and care (ECEC) includes cooperation among personnel, with guardians and the local area (EDUFI, 2017). In recent years, nongovernmental organizations (e.g., MLL [Mannerheim League for Child Welfare], Finnish Red Cross) have organized voluntary grannies' and grandads' regular visits in pre-primary programs and kindergartens. Grandparents' participate in children's activities, such as play, daytrips, or reading fairy tales. In the preprimary class that participated in this study, the cooperation with older students is emphasized, but parents and grandparents also have active roles in the class. This kind of cooperation creates a strong sense of social well-being, and more detailed research concerning everyday technologies and craft is needed. 
Virpi YLIVERRONEN, Marja-Leena RÖNKKÖ \& Kaiju KANGAS - Learning everyday technologies through playful experimenting and cooperative making in pre-primary education

\section{REFERENCES}

Aerila, J-A., Rönkkö, M-L., \& Grönman, S. (2019). Art-Based activities and stories convey children's learning experiences. In J-A. Aerila \& K. J. Kerry-Moran (Eds.), Story in children's lives: Contributions of the narrative mode to early childhood development, literacy, and learning (pp. 333-354). Springer Nature.

Anning, A. (1997). Drawing out ideas: Graphicacy and young children. International Journal of Technology and Design Education, 7, 219-239. https://doi.org/10.1023/A:1008824921210

Bequette, J. W., \& Bequette, M. B. (2012). A place for art and design education in the STEM conversation. Art Education, 65(2), 40-47. https://doi.org/10.1080/00043125.2012.11519167

EDUFI. (2017). Finnish national agency for education, national core curriculum for early childhood education and care 2016. EDUFI.

Fleer, M. (2000). Working technologically: Investigations into how young children design and make during technology education. International Journal of Technology and Design Education, 10, 43-59. https://doi.org/10.1023/A:1008923410441

FNBE. (2016). National core curriculum for pre-primary education 2014. Finnish national board of education.

Ge, X., Ifenthaler, D., \& Spector, J. M. (2015). Moving forward with STEAM education research. In X. Ge, D. Ifenthaler \& J. M. Spector (Eds.), Emerging technologies for STEAM education: Full STEAM ahead (pp. 383-395). Springer.

Hope, G. (2008). Thinking and learning through drawing in primary classrooms. Sage.

Kafai, Y. B., Fields, D. A., \& Searle, K. A. (2014). Electronic textiles as disruptive designs: Supporting and challenging maker activities in schools. Harvard Educational Review, 84(4), 532-565. http://dx.doi.org/10.17763/haer.84.4.46m7372370214783

Leong, D. J., \& Bodrova, E. (2012). Assessing and scaffolding make believe play. Young Children, 67(1), 28-34.

Lindeman, K. W., Jabot, M., \& Berkley, M. T. (2014). The role of STEM (or STEAM) in the early childhood setting. In L. E. Cohen \& S. Waite-Stupiansky (Eds.) Learning across the early childhood curriculum. Advances in early education and day care, (pp. 95-114). Emerald Group Publishing Limited.

Mead, S., Hilton, D., \& Curtis, L. (2001). Peer support: A theoretical perspective. Psychiatric Rehabilitation Journal, 25(2), 134-141.

Mead, S., \& MacNeil, C. (2004). Peer support: What makes it unique? International Journal of Psychosocial Rehabilitation 10(2), 29-37.

Pavlou, V. (2009). Understanding Young Children's Three-Dimensional Creative Potential in Art Making. International Journal of Art \& Design Education, 28(2), 139-150.

Piaget, J., \& Inhelder, B. (1979). The psychology of the child. Routledge.

Pöllänen, S. (2019). Perspectives on multi-material craft in basic education. International Journal of Art \& Design Education, 1-16. https://doi.org/101111/jade.12263

Reiser, B. J., \& Tabak, I. (2014). Scaffolding. In R. K. Sawyer (Ed.), The Cambridge handbook of the learning sciences (pp. 44-62). Cambridge University Press.

Rönkkö, M.-L., Yliverronen, V., \& Kangas, K. (2021). Investigative activity in pre-primary technology education: The Power Creatures project. Design and Technology Education: an International Journal, 26(1), 29-44. https://ojs.lboro.ac.uk/DATE/article/view/2885

Rönkkö, M-L., \& Aerila, J-A. (2015). Children designing a soft toy. An LCE model as an application of the experiential learning during the holistic craft process. Techne Series A, 22(1), 44-58. https://journals.oslomet.no/index.php/techneA/article/view/988

Sawyer, R. K. (2006). Analyzing collaborative discourse. In R. K. Sawyer (Ed.), The Cambridge handbook of the learning sciences (pp. 187-204). Cambridge University Press.

Sousa, D. A., \& Pilecki, T. (2018). From STEM to STEAM: Brain-compatible strategies and lessons that integrate arts (2nd ed.). SAGE. http://dx.doi.org/10.4135/9781544357393 
Virpi YLIVERRONEN, Marja-Leena RÖNKKÖ \& Kaiju KANGAS - Learning everyday technologies through playful experimenting and cooperative making in pre-primary education

Sundqvist, P., \& Nilsson, T. (2018). Technology education in preschool: providing opportunities for children to use artifacts and to create. International Journal of Technology and Design Education, 28(1), $29-51$. https://doi.org/10.1007/s10798-016-9375-y

Turja, L., Endepohls-Ulpe, M., \& Chatoney, M. (2009). A conceptual framework for developing the curriculum and delivery of technology education in early childhood. International Journal of Technology and Design Education, 19(4), 353-365. https://doi.org/10.1007/s10798-009-9093-9

Turja, L. (2011). Teknologiakasvatus varhaisvuosina. [Technology education in early years]. In E. Hujala \& L. Turja (eds.), Varhaiskasvatuksen käsikirja [Handbook of Early Childhood education] (pp. 195-207). PSkustannus.

Vygotsky, L. S. (1986). Thought and language. MIT Press.

Welch, M. (1998). Students' use of three dimensional modelling while designing and making a solution to a technological problem. International Journal of Technology and Design Education, 8(3), 241-260. https://doi.org/10.1023/A:1008802927817

Yliverronen, V. (2014). From story to product: Pre-schoolers' designing and making process in a holistic craft context. Design and Technology Education: An International Journal, 19(2), 8-16. https://ojs.lboro.ac.uk/DATE/article/view/1954 